\title{
Holocene sequences in the Mayan Lowlands - A provenance study using heavy mineral distributions
}

\author{
Berenice Solís-Castillo, Christine Thiel, Héctor Cabadas Baez, Elizabeth Solleiro Rebolledo, Sergey Sedov, \\ Birgit Terhorst, Bodo Damm, Manfred Frechen, Sumiko Tsukamoto
}

How to cite:

Solís-Castillo, B., Thiel C., Cabadas Baez, H., Solleiro Rebolledo, E., Sedov, S., Terhorst, B., Damm, B., Frechen, M., Tsuкамото, S. (2013): Holocene sequences in the Mayan Lowlands - A provenance study using heavy mineral distributions. - E\&G Quaternary Science Journal, 62 (2): 84-97. DOI: 10.3285/eg.62.2.01

Abstract:

Heavy mineral analysis of alluvial sediments and paleosols on Holocene terraces of the Usumacinta River provided an effective tool to reconstruct sediment provenance in the Mayan Lowlands. Furthermore, the mineralogical data are useful for pedostratigraphic correlations in the region. Based on our observations from the Tierra Blanca profile, the ultrastable detrital heavy minerals assemblage (mostly zircon, tourmaline, and rutile) are the most promising mineral proxies to recognize the provenance of the sediments. Those minerals are accompanied by an intriguing variety of high density authigenic minerals (including titanite). Using the specific characteristics and the ages obtained for some layers, it may now be possible to develop a regional chronostratigraphy for the paleosols and alluvial sequences. Our data suggest that sediments were transported westward in river channels originating from the highlands of Guatemala. The studied materials also contain high amounts of volcanic minerals, most of them fresh and with angular shapes, thus indicating a proximal source, mostly likely from Tacana Volcano, Mexico/Guatemala.

Holozäne Sequenzen in den Tieflandgebieten der Mayas - Eine Untersuchung der Liefergebiete auf Basis von Schwermineralgesellschaften

Kurzfassung:

Schwermineralanalysen an alluvialen Sedimenten und Paläoböden des Usumacinta-Flusses sind ein sehr effektives Werkzeug für die Rekonstruktion der relevanten Liefergebiete in den Tieflandgebieten der Mayas. Die mineralogischen Daten können für die pedostratigraphische Korrelation in der Region nützlich sein. Auf der Basis unserer Beobachtungen für Tierra Blanca ist die ultrastabile Schwermineralkomponente (zumeist Zirkon, Turmalin und Rutil) besonders erfolgversprechend für den Nachweis der Liefergebiete der Sedimente. Diese Minerale treten gemeinsam mit einer großen Vielfalt von sehr dichten authigenen Mineralen auf (u.a. Titanit). Unter Berücksichtigung der spezifischen Eigenschaften und der Alter von ausgewählten Horizonten, kann nun versucht werden, eine regionale Chronostratigraphie für Paläoböden und alluviale Sequenzen zu entwickeln. Unsere Daten deuten auf Sedimenttransport in Flussrinnen von den Hochländern Guatemalas gen Westen hin. Die untersuchten Schichten enthalten auch große Anteile an vulkanischen Mineralen mit frischen und eckigen Formen, was auf ein proximales Liefergebiet (wahrscheinlich Tacana Volcano, Mexico/Guatemala) hinweist.

Keywords: $\quad$ heavy mineral assemblages, pedostratigraphy, micromorphology, alluvial sediments, Mayan Lowlands, Mexico

Addresses of authors: B. Solís-Castillo, Posgrado en Ciencias de la Tierra. Instituto de Geología, UNAM. 04510, México, D.F., E-Mail bsolisc.geologia@gmail.com; C. Thiel, Nordic Laboratory for Luminescence Dating, Department of Geoscience, Aarhus University, Risø Campus, Frederiksborgvej 399, 4000 Roskilde, Denmark; Center for Nuclear Technologies, Technical University of Denmark, Risø Campus, Frederiksborgvej 399, 4000 Roskilde, Denmark. E-Mail: chrth@dtu.dk; H. Cabadas Baez, Laboratorio de Geología, Facultad de Geografía, UAEM. 50110, Toluca Edo. México. hvcabadasb@uaemex.mx; E. Solleiro Rebolledo, S. Sedov, Instituto de Geología, UNAM. 04510, México, DF. E-Mail: solleiro@geologia.unam.mx; serg_sedov@yahoo.com; B. Terhorst, Institute of Geography and Geology, University of Würzburg, Am Hubland, 97047 Würzburg, Germany. birgit.terhorst@uni-wuerzburg.de; B. Damm, Institut für Strukturforschung und Planung in agrarischen Intensivgebieten (ISPA), Vechta University, 49364 Vechta. E-Mail: bdamm@ispa.uni-vechta.de; M. Frechen, S. Tsukamoto, Leibniz Institute for Applied Geophysics Section, S3: Geochronology and Isotope Hydrology, Stilleweg 2, 30655 Hannover, Germany. E-Mail: manfred.frechen@liag-hannover.de; E-Mail: sumiko.tsukamoto@liag-hannover.de

\section{Introduction}

The reconstruction of the environmental and landscape changes in Mexico for the Late Quaternary is based on numerous data. The majority of data is derived from lacustrine sediments, glacial and paleopedological records; however, due to the fragmentary character of glacial records, hiatuses in lake cores, and low temporal resolution of te- phra-paleosols sequences these records are still contradictory (SEDov et al. 2007). With respect to this problem, new insights might be obtained by studying alluvial sequences. Until now the alluvial and fluvial archives in Mexico have not received sufficient attention as a source to understand short-term changes in the landscape; only very few detailed studies deal specifically with flu- 


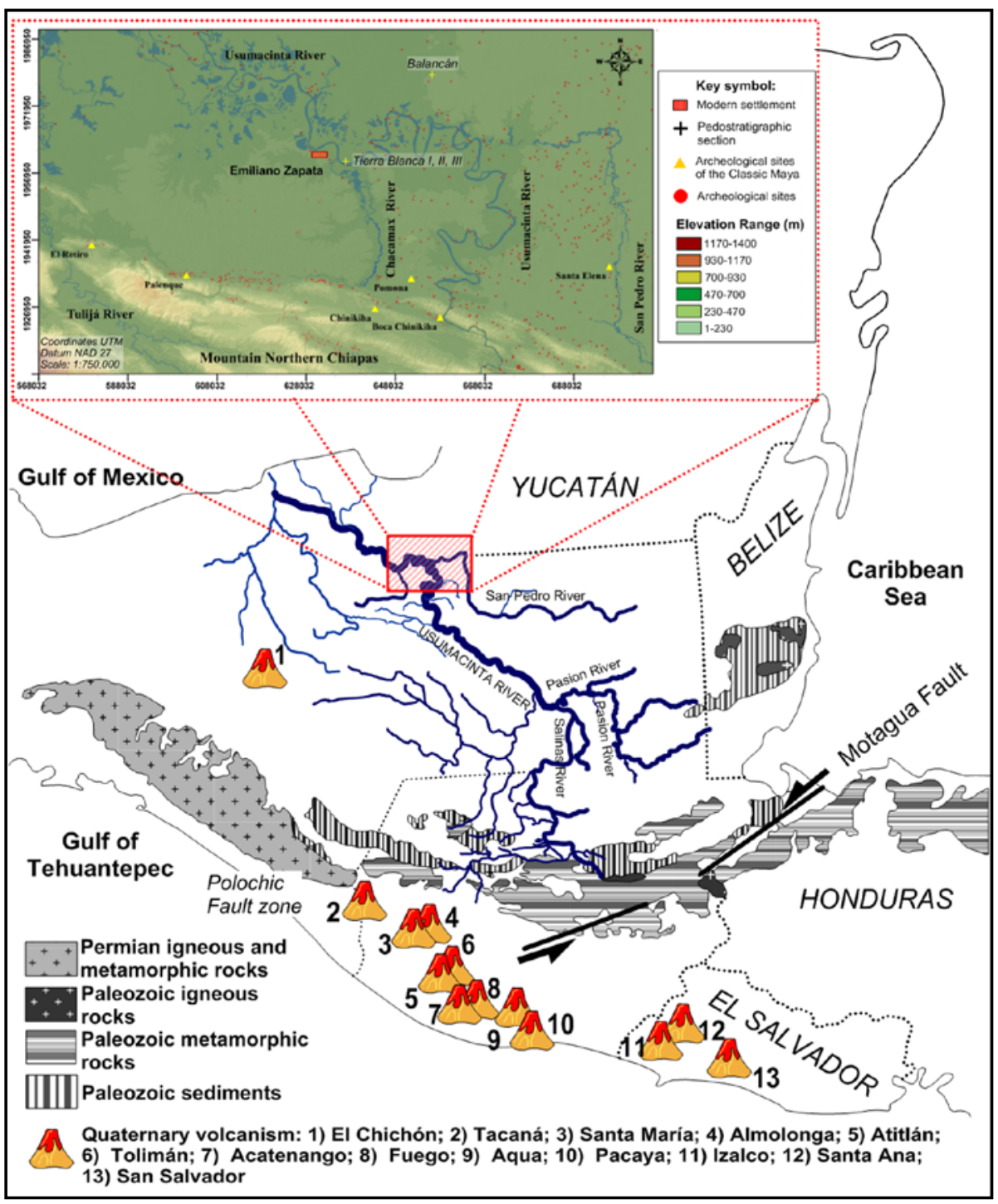

Fig. 1: Location of the study area and simplified geological map showing the boundary between the Maya and the Chortis blocks. Modified after ORTEGA-GUTIÉRREZ et al. (1992), and FRENCH \& SCHENK (1997). Abb. 1: Lage des Untersuchungsgebiets und vereinfachte Darstellung der regionalen Geologie mit der Grenze zwischen der Maya- und der Cortis-Platte. Verändert nach ORTEGA-GUTIÉRREZ et al. (1992)und FRENCH \& SCHENK (1997). vial Late Pleistocene-Holocene sequences (cf. SolleIroReBolledo et al. 2011).

Particularly, the alluvial-paleosol sedimentary sequences in the Southeast of Mexico are highly sensitive to the environmental changes and are rich and detailed Holcene archives (Solís-CASTILlo et al. 2013). However, river systems are very complex due to the dynamics involved in their formation, thus controlling the different phases of aggradation, degradation, and pedogenesis. Aggradation phases can be recognized by selective sorting of particles due to differential entrainment and transport. This is especially seen in the characteristics of heavy minerals, such as densitiy, grain size and shape. In general, the sorting may be a result of ancient depositional environments and provenance of sediments (KOMAR 2007). In rivers with high sedimentation rates, heavy minerals are affected by considerable sorting before they reach the alluvial plain (PIRKLE et al. 2007).

Alluvial landscapes are very complex due to the presence of discontinuities in vertical successions, being controlled by several forces (climatic, geologic, geomorphic, anthropogenic), and interpretation of the successions can be problematic. Similar sediments can be produced in different and distant areas or periods; this makes paleoenvironmental reconstruction difficult. In consequence, paleosols are important records for the environmental history and can help to unravel the alluvial stratigraphy (HugHes 2010). Alluvial soils exhibit characteristics of both sedimentary and soil formation processes. Such soils are characterized by the textural and mineralogical composition of the material transported across the drainage basins (KRAUs 2002). Traditionally, analyses of mineral composition have been applied to paleosols on surfaces of different ages to establish morphostratigraphical units (SCHATZL \& ANDERson 2005). In particular, heavy minerals in soils are used as indicators for sediment provenance. Furthermore, heavy minerals have been used to determine weathering degrees, thus being useful as relative dating tools (Mikesell et al. 2004). In sequences where paleosols show contrasting differences, weathering indices are commonly used to evaluate the intensity of the process and their relation to environmental conditions.

The Usumacinta River in Tabasco, Mexico (Fig. 1) has carried vast quantities of sediments from Chiapas and Guatemala since the Plio-Pleistocene and therefore exhibits a great potential for the application of heavy mineral analyses. At present, detailed information on the heavy mineral assemblages in soils are very scarce for the Mayan Lowlands. This area is known for its high cultural diversity since the MidHolocene, which is probably related to the river-channel stability and soil formation on the Holocene terraces, thus 
providing space for settlements in the alluvial plain (SoLÍsCAstillo et al. 2013).

Altogether, the analysis of mineral provenance is of great importance to better understand the river dynamics and climatic changes in this region, which is reflected in different weathering intensities. Unraveling the changes in the landscape and in the soils will contribute to a better understanding of human migration along the Mayan Lowlands.

It is surprising that most of the information about the climate history of the Maya region comes from studies in $\mathrm{Yu}-$ catan (Rosenmeier et al. 2002; Hodell et al. 2005; Sedov et al. 2007; FrEDick et al. 2008; CABADAs et al. 2010), as well as from Guatemala and Belize (DAHLIN et al. 1980; BEACH et al. 2003; FERnANDEZ et al. 2005; DunNing et al. 2002, 2006). Until now, for the Maya Lowlands, only Solís-CAstillo et al. (2013) provided data on the reconstruction of Holocene climatic changes in the Usumacinta River region on the base of paleopedology.

The authors found that the Late Pleistocene-Early Holocene paleosols show strong weathering and gleyzation related to more humid climatic conditions. These conditions were only observed in the paleosols with gleyic features, while in the alluvial sediments only few oxidereduction characteristic were found. Mid-Holocene paleosols are characterized by the presence of carbonate concretions combined with vertic features, which indicate a major drying trend as well as fluctuations between wet and dry conditions. Late Holocene paleosols show vertic properties and lack gleyic features; this corresponds to dryer conditions. Further, Middle and Late Holocene paleosols are observed at the base of other sequences located on the younger terraces; these paleosols do not show any signs of oxide-reduction conditions.

In this study we use heavy minerals to detect the weathering degree of alluvial sediments and paleosols; these data serve as proxy for the relative stability during the Late Pleistocene and the Holocene. Some samples were selected for micromorphology in order to investigate the bulk mineral composition.

Furthermore, the composition of the heavy minerals from the alluvial sediments of the Usumacinta River helped to reconstruct the provenance. In addition, radiocarbon and luminescence ages provide a numerical chronology for the sediments under study.

\section{Regional setting and the Usumacinta River}

The Mayan Lowlands are characterized by active volcanoes, rugged terrain of the Sierra de Chiapas and the Central Cordillera, and faulting as well as extensive karst systems in the northern lowlands (Figure 1). Volcanism and tectonics are a result of the highly variable spatial and temporal evolution of plate boundaries between Cocos, North American, and Caribbean Plates (Donnelly et al. 1990).

The Sierra de Chiapas is mainly formed by Tertiary folded, northwest-southeast oriented limestones. The limestones show extensive karstic features with abundant subterranean drainage and ephemeral surface streams. The highlands of the Chiapas region are composed of extru- sive igneous rocks (andesites, dacites, and pyroclastic products) and sedimentary rocks (shales, sandstones, and limestones). Their ages range from Late Cretaceous to Tertiary, and Quaternary (HernANDEz et al. 2012). The Paleozoic geology in Chiapas is characterized by metamorphic rocks, which consist of granitic gneiss and gneiss of biotite and orthoclase, sedimentary rocks, and biotite schists. In the western part of Guatemala, gneiss and schists of quartz are present. The Paleozoic Granitic Massif of Chiapas is composed of pink granite of biotite with graduation to granodiorite (Monografia Geologica-Minera del Estado DE TABAsco 1999).

The Usumacinta River is one of the larger fluvial systems in Mexico with a drainage area of $63,804 \mathrm{~km}^{2}$ (WEst et al. 1969), which flows through both the highlands of Chiapas and Guatemala and the coastal plains of the southern Gulf of Mexico.

The latter are formed by Late Tertiary (Pliocene) and Quaternary deposits, which are mainly composed of alluvium, lacustrine and marsh sediments, as well as coastal bars and residual soils. During the Holocene, three tributary channels (San Pedro in the east, Chakamax in the center, and Tulijá in the west) flew across the terraces of the Central Usumacinta and discharged into the Lower Usumacinta (Solís-CAstillo et al. 2013).

Starting in Guatemala, the Usumacinta River runs northeast to the Bay of Campeche in the Gulf of Mexico (Figure 1). This vast region has been subdivided into two main areas: the Upper Usumacinta (from the rivers Salinas and Passion in Guatemala to Boca del Cerro, Chiapas), and the Lower Usumacinta (from Boca del Cerro to the Gulf of Mexico). In pre-Hispanic times, several population centers were located in these areas. Until now, there is evidence of 2,300 archeological sites with different characteristics; they are preferably located in the plains of Tabasco. The number of occupation sites in the numerous side valleys along the Usumacinta River in the mountainous region is still unknown (LIENDO et al. 2012). The archeological research has revealed a long sequence of occupation for the region ranging from the Middle Preclassic period (800-300 B.C.) to the Terminal Classic period (850 A.D.) (LIENDO et al. 2012, and references therein).

In the north, the Usumacinta River flows through the State of Tabasco in an alluvial valley composed of PlioPleistocene to Holocene terraces (OrTIZ-PEREZ et al. 2005); these are affected by Neogene tectonic activity with a set of normal faults causing a horst-graben system (PADILLA \& SANCHEZ 2007). The main tributaries follow normal fault planes. The oldest terraces are located in the areas more distant from the sea. In contrast, Holocene terraces are formed by incisions and floodplain deposits along the main channel. Three levels of Holocene terraces have been recognized by Solís-CAstillo et al. (2013), referred to as HT2 (at 15-10 m asl), HT1 (at 10-5 m asl) and HT0 (at $<5 \mathrm{~m}$ asl), from the oldest to the youngest.

\section{Materials}

In Tierra Blanca (Figure 1), the studied sequence is composed of alluvial sediments intercalated with paleosols. Three profiles were studied (Figure 2): Tierra Blanca (TB) I, TB II and TB III. Solís-CASTILlo et al. (2013) have 
presented soil morphologic data, archeological and cultural evidence, as well as radiocarbon ages for TB I and TB II (amongst other sections from the same region). Here, we present new data for TB III and compare them to TB I and II in order to get a more complete understanding of the landscape formation and paleoenvironmental changes. A composite profile is shown in Figure 3. The pedological and sedimentological survey is complemented by micromorphology. Furthermore, three alluvial layers were dated using optically stimulated luminescence (OSL); these ages can be compared with the radiocarbon ages presented in Solís-CAstillo et al. (2013). Heavy mineral analysis is used to trace the provenance. In addition to the Tierra Blanca site, data from a sequence in Balancán (Figure 1) are presented; the section in Balancán is also located on a Pleistocene terrace of the Usumacinta River.

The TB I, II and III sequences are located on the oldest Holocene terrace (HT2), and represent the most complete stratigraphic section of the area. In TB I and TB II two types of paleosols are present, gleyic at the base and vertic at the top. They are clearly separated by alluvial sediments (TB III) (Figure 3).

On top of a sandy Pleistocene alluvium the lower part of the composite profile (TB I) contains four paleosols (numbered $6,7,8,9)$. This section with a total thickness of 267 $\mathrm{cm}$, is characterized by the following horizons: $6 \mathrm{G}, 7 \mathrm{Bg}, 8 \mathrm{G}$, $8 \mathrm{Gk}, 9 \mathrm{G}, 9 \mathrm{Bkg}$, 9BCgk (Figure 3). A horizons are not preserved due to erosional processes; there is no separation of the individual paleosols by $\mathrm{C}$ horizons. All horizons show strong gleyic features expressed as grayish brown colors with reddish-yellowish-greenish mottles, coarse subangular blocky structure, Fe concretions and/or spots, and dendritic $\mathrm{Mn}$. In the paleosols of unit 9 the gleyic features decrease with depth, and at the base of horizon 9BCgk the oxidereduction characteristics are less. The strongest gleyic features are observed in paleosol 6, where also slickensides are present. One of the most remarkable features in the gleyic unit in horizon $9 \mathrm{Bkg}$ is the presence of hard carbonate concretions, around 5 to $10 \mathrm{~cm}$ in diameter. These concretions were radiocarbon dated to $5450-5380$ cal. B.P. (3240-3110 B.C.) (Solís-CAstillo et al. 2013).

The upper paleosols (section TB II; Figure 3) formed on top of silty sediment (i.e. on top of section TB III; Figure 3). The paleosols in section TB II (labeled as paleosols 2, 3, 4, 5) show evidence of human occupation in three different periods (according to the Mesoamerican chronology): Formative (800 B.C. - A.D. 150), Classic (A.D. 150-1000) and Post-classic (A.D. 1000-1500). Paleosols 2 and 3 are weakly developed. Horizon $4 \mathrm{Bk}$ is a pedosediment, composed of soil fragments and broken carbonate concretions. Paleosol 5 bears the strongest pedogenic features of all paleosols, and can be subdivided in 5Ass, 5Bss and 5BC, with a total thickness $>1 \mathrm{~m}$. This paleosol shows strong vertic features: slickensides, hard angular blocky structure, and vertical cracks. Carbonates in the form of white spots and filling fractures and pores are found throughout the entire profile. The modern surface is made up of $\sim 100 \mathrm{~cm}$ of alluvial sediment little affected by pedogenesis (C horizon).

The chronology of these paleosols has been previously established by radiocarbon dating (Table 1) and archeological evidence (Solís-CASTILlo et al. 2013). The soil organic matter (SOM) in 5Ass was dated to $2340-2300 \mathrm{cal}$. B.P. (390-350 B.C.) The carbonates disseminated in 5Bss horizon gave a much younger age, 720-660 cal B.P. (1230-1290 A.D.). However, artifacts found in this paleosol belong to the Formative Period (1800 B.C. -150 A.D.), which confirms its stratigraphic position. Clearly, the carbonates must have formed later. Charcoal from the 3A horizon yielded an age of 1140-970 cal. B.P. (810-980 A.D.). Classic ceramic fragments (A.D. 150-1000) recovered from this paleosol support this date. The upper paleosol 2 has not been dated with any numerical technique; however it contains Post-classic artifacts (A.D. 1000-1500) and thus allows for assigning an age to it.

The alluvial sediments were best expressed in profile TB III located only $10 \mathrm{~m}$ to the east of TB I. At the contact to

Tab. 1: Summary of the dating results. Blue OSL data are from quartz, pIRIR ${ }_{290}$ are from K-feldspar. For sample 2464, the quartz is in saturation, i.e. a minimum dose and correspondingly age are given. The radiocarbon ages are taken from SOLÍS-CASTILLO et al. (2013).

Tab. 1: Zusammenfassung der Datierungsergebnisse. Blaue OSL-Daten stammen von Quarz, pIRIR 290 von K-Feldspat. Der Quarz für Probe 2464 ist in Sättigung, d.h. es kann nur eine Mindestdosis und ein -alter angegeben werden. Die Radiokarbonalter stammen aus Solís-CASTILLO et al. (2013).

\begin{tabular}{|c|c|c|c|c|c|c|c|c|}
\hline \multirow[t]{2}{*}{ Lab code } & \multirow[t]{2}{*}{ Horizon } & \multicolumn{2}{|c|}{ Dose rate [Gy/ka] } & \multicolumn{2}{|c|}{ Equivalent dose [Gy] } & \multicolumn{2}{|c|}{ Age [ka] } & \multirow{2}{*}{$\begin{array}{c}\text { Radiocarbon age } \\
\text { cal. BP }[2 \sigma]\end{array}$} \\
\hline & & quartz & feldspar & blue OSL & $p \mid R I R_{290}$ & blue OSL & $p|R| R_{290}$ & \\
\hline BETA-300447 & $3 \mathrm{~A}$ & - & - & - & - & - & - & $1140-970^{[3]}$ \\
\hline 2462 & $3 C$ & $2.90 \pm 0.11$ & - & $6.1 \pm 1.4^{[1]}$ & - & $2.1 \pm 0.5$ & - & \\
\hline BETA-300448 & 5Ass & - & - & - & - & - & - & $2340-2300^{[4]}$ \\
\hline BETA-300449 & 5Bss & - & - & - & - & - & - & $720-660^{[5]}$ \\
\hline 2463 & TB3_07 & $3.27 \pm 0.11$ & - & $29 \pm 6^{[1]}$ & - & $9 \pm 2$ & - & - \\
\hline BETA-277572 & $9 \mathrm{Bkg}$ & - & - & - & - & - & - & $5450-5380^{[5]}$ \\
\hline 2464 & 9BCgk & $1.98 \pm 0.10$ & $2.61 \pm 0.11$ & $>130^{[2]}$ & $322 \pm 10^{[2]}$ & $>65$ & $123 \pm 6$ & - \\
\hline
\end{tabular}

$1>24$ aliquots measured.

29 aliquots measured.

${ }^{3}$ Charcoal dated.

${ }^{4}$ Soil organic matter dated.

${ }^{5} \mathrm{CaCO}_{3}$ nodules dated. 


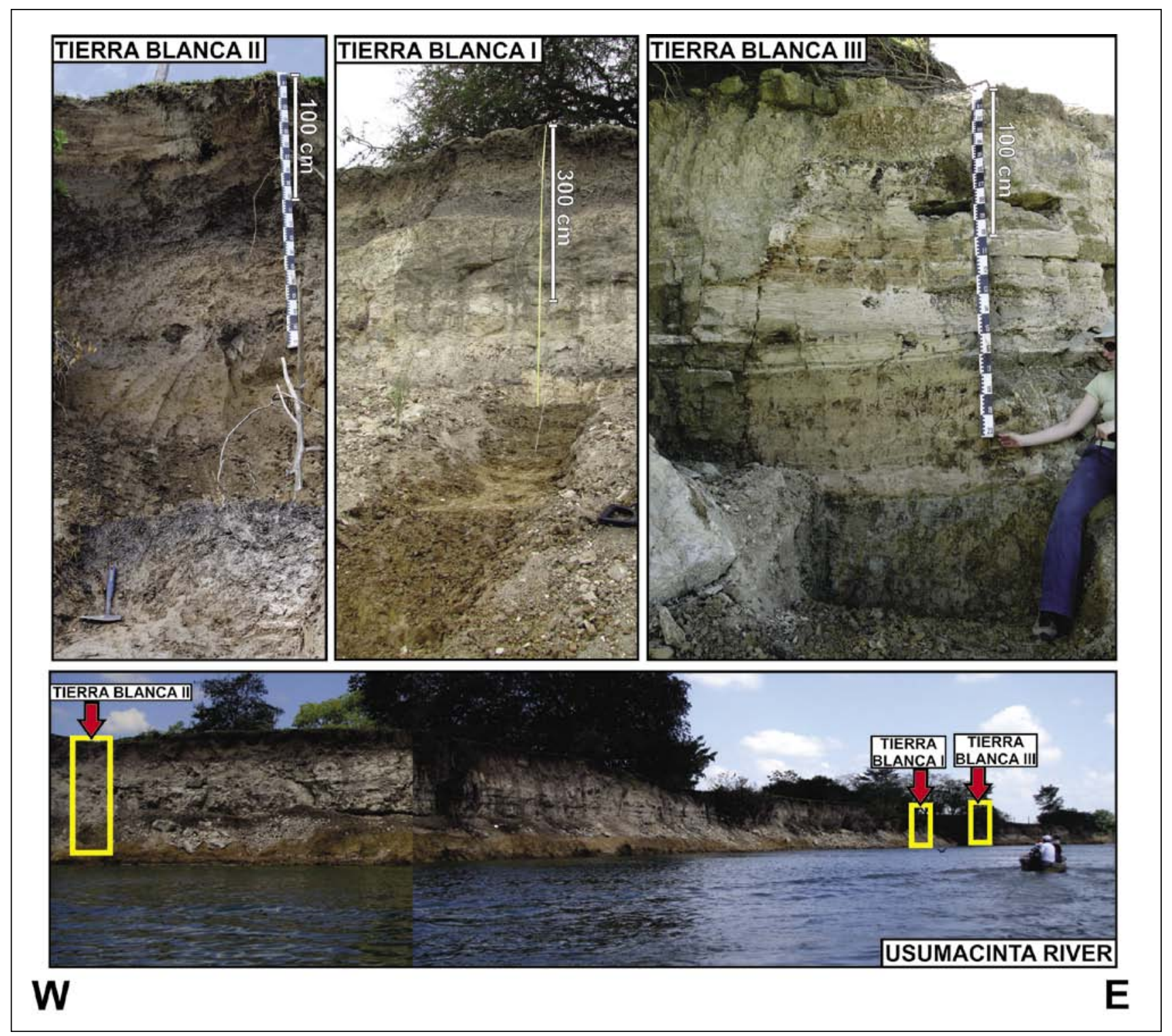

Fig. 2: Photograph showing the positions of the individual profiles in Tierra Blanca.

Abb. 2: Übersichtsaufnahme von Tierra Blanca und einzelne Profile.

paleosols with evidence of human occupation, the overlying sediment is laminated and shows a wavy boundary and has a total thickness of $10 \mathrm{~cm}$. The middle part alternates from lamination to crossed stratification and is characterized by a sand texture, reductomorphic features and carbonate concretions. In this section, two phases representing slow water flow or even standing water can be found (as shown by clayey material with some reductomorphic features and root traces).

The upper part is also laminated, with vertical cracks up to $40 \mathrm{~cm}$ in length cutting through the sediment layer (cf. Figure 3). The material of all laminated strata reacts intensively with $\mathrm{HCl}$. We refer to this material as silt sediment due to the dominance of this fraction (62\%); however, it also has a high proportion of clay (32\%) (Solís-CASTILlo et al. 2013).

Another profile situated on top of a Pleistocene terrace is found in the Balancán section (Figure 4). It is characterized by a monogenetic soil $\left(\mathrm{A} / \mathrm{Bg} / \mathrm{G}_{1} / \mathrm{G}_{2}\right)$ with strong gleyic features (grayish brown colors with reddish-yellowishgreenish mottles, Fe concretions and dendritic $\mathrm{Mn}$ ). The soils at Balancán are morphologically similar to the ones at the base of the Tierra Blanca sequence. However, the Balancán soils are more intensely weathered as shown by the larger amount of clay, and the more compact and pronounced oxide-reduction features (Figure 4).

\section{Methods \\ 4.1 Mineralogy and micromorphology}

Thirty-two samples were taken for heavy mineral analyses (cf. Figure 5). The fine sand $(63-125 \mu \mathrm{m})$ was separated by sieving and pretreated with $10 \%$ hydrocholoric acid $(\mathrm{HCl})$ to dissolve carbonates, and subsequently with $30 \%$ hydrogen peroxide $\left(\mathrm{H}_{2} \mathrm{O}_{2}\right)$ to remove organic matter. The sands were dried and then floated in sodium polytungstate liquid with a density of $2.82 \pm 0.02 \mathrm{~g} / \mathrm{cm}^{3}$. Heavy minerals were collected in filters and after drying dispersed in Mountex resin with a refraction index of $\mathrm{N}=1.67$. The identification of the minerals was conducted under a polarization microscope after MANGe \& MAURER (1992). Two hundred mineral grains were counted for each sample.

We furthermore took three samples representative for the 
three types of materials found: the gleyic paleosols at the base (9Bgk horizon, TB I); the paleosols with signs of human occupation (3A horizon, TB II), and the top of the silty sediment (TB3_00, TB III; cf. Figure 3). Using micromorphology the bulk mineral composition was applied, focusing on the light minerals. The thin-sections ( $30 \mu \mathrm{m}$ thick) were prepared from undisturbed soil samples, impregnated at room temperature with resin Cristal MC-40. They were studied under a petrographic microscope, and described following the terminology of BuLlock et al. (1985). Additionally, the thin section of the silty sediment was scanned with high resolution, 4800 and 9600 dots per inch (DPI) in order to investigate its overall structure.

\subsection{Luminescence dating}

Luminescence samples were taken by hammering metal tubes into the freshly cleaned profile (cf. Figures 2 and 3); the tubes were sealed to prevent any light intrusion. Additional samples for dose rate determination (dosimetry) were taken from immediately around the tube samples. The luminescence samples were treated under subdued orange light. The material from the outer ends of the tubes was discarded, and the samples were then dried prior to sieving. The fraction $100-150 \mu \mathrm{m}$ was treated with $30 \% \mathrm{HCl}, 10 \%$ $\mathrm{H}_{2} \mathrm{O}_{2}$, and sodium oxalate prior to density separation using sodium polytungstate (quartz: $\rho<2.7 \mathrm{~g} / \mathrm{cm}^{3}$ but $>2.62 \mathrm{~g} /$ $\mathrm{cm}^{3}$; potassium (K)-rich feldspar $\rho<2.58 \mathrm{~g} / \mathrm{cm}^{3}$ ). The quartz grains were subsequently etched at least once in $30 \%$ hydrofluoric acid (HF) for 1 hour, while the feldspar grains only got a short (20 minutes) HF etch $(10 \%)$ to remove the outer layer of the grains. Finally all fractions were treated with $30 \% \mathrm{HCl}$ to destroy any fluorides that might have build up during HF etching.

The equivalent doses $\left(\mathrm{D}_{\mathrm{e}}\right)$ were measured with automated Risø TL/OSL readers as small (samples 2463 and 2464) or medium (sample 2462) aliquots mounted on stainless steel cups. Both infrared (IR) light emitting diodes (LED) and blue LEDs were used. For the quartz extracts the luminescence was detected through a Hoya U340 filter, whilst feldspar detection was through a Schott BG39/Corning 7-59 filter (IR stimulation). All measurements procedures are single aliquot regenerative (SAR) protocols (MURRAY \& WINTLE 2000).

Quartz purity checks showed that some aliquots of samples 2462 and 2463 exhibited contamination from IR sensitive material (most likely feldspar), even though the average IR depletion ratio (DULLER 2003) was within 10\% of unity. To ensure a quartz signal as pure as instrumentally possible from all aliquots, a double SAR (BANERJEE et al. 2001) was applied using a preheat of $200^{\circ} \mathrm{C}(10 \mathrm{~s})$ and a cutheat of $180^{\circ} \mathrm{C}$. IR and blue stimulation were for $100 \mathrm{~s}$ at $125^{\circ} \mathrm{C}$. At the end of each cycle, a high temperature blue clean-out $\left(280^{\circ} \mathrm{C}\right.$ for $\left.40 \mathrm{~s}\right)$ was inserted. The quartz of 2464 was measured without the IR step as it was found to be clean (IR depletion within $2 \%$ of unity); the preheat temperature was $260^{\circ} \mathrm{C}$ and the cutheat temperature $220^{\circ} \mathrm{C}$, respectively. Early background subtraction (CUNningham \& WALlinga, 2010) was used to calculate the equivalent doses.

Because the quartz for sample 2464 was found to be in saturation (cf. results section and Table 1), equivalent

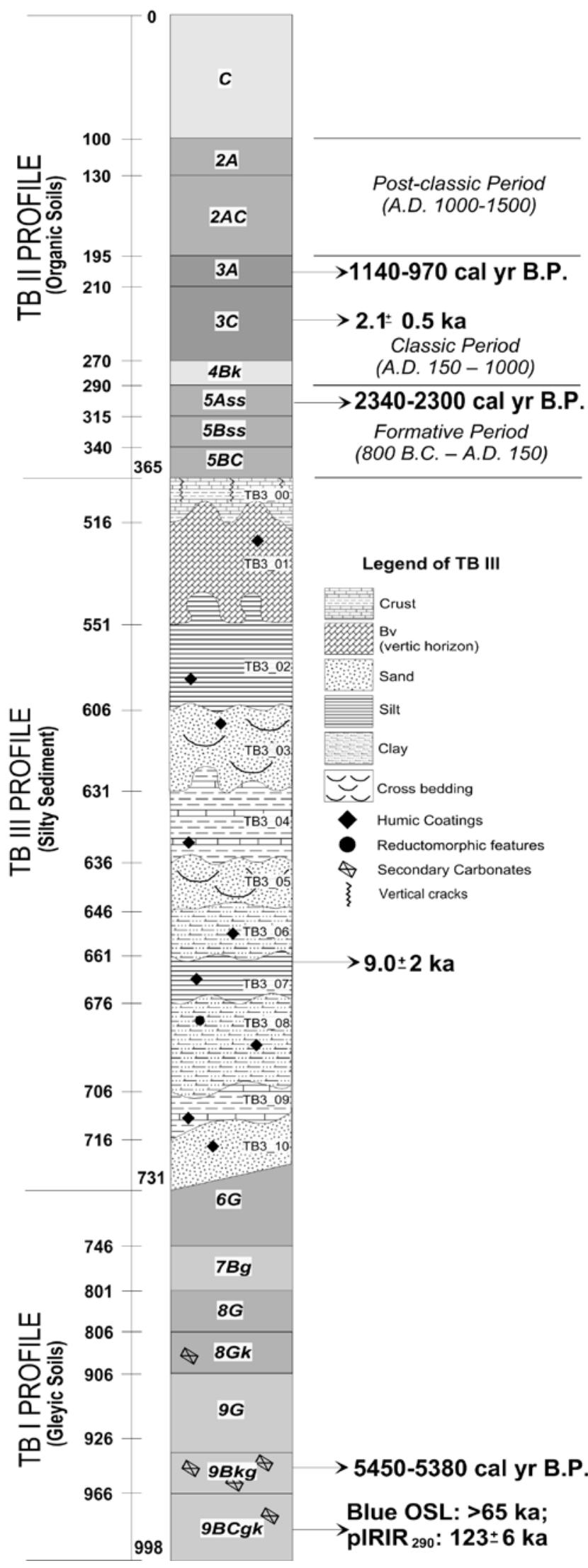

Fig. 3: Tierra Blanca: composite profile and ages. Abb. 3: Gesamtprofil und Alter für Tierra Blanca. 


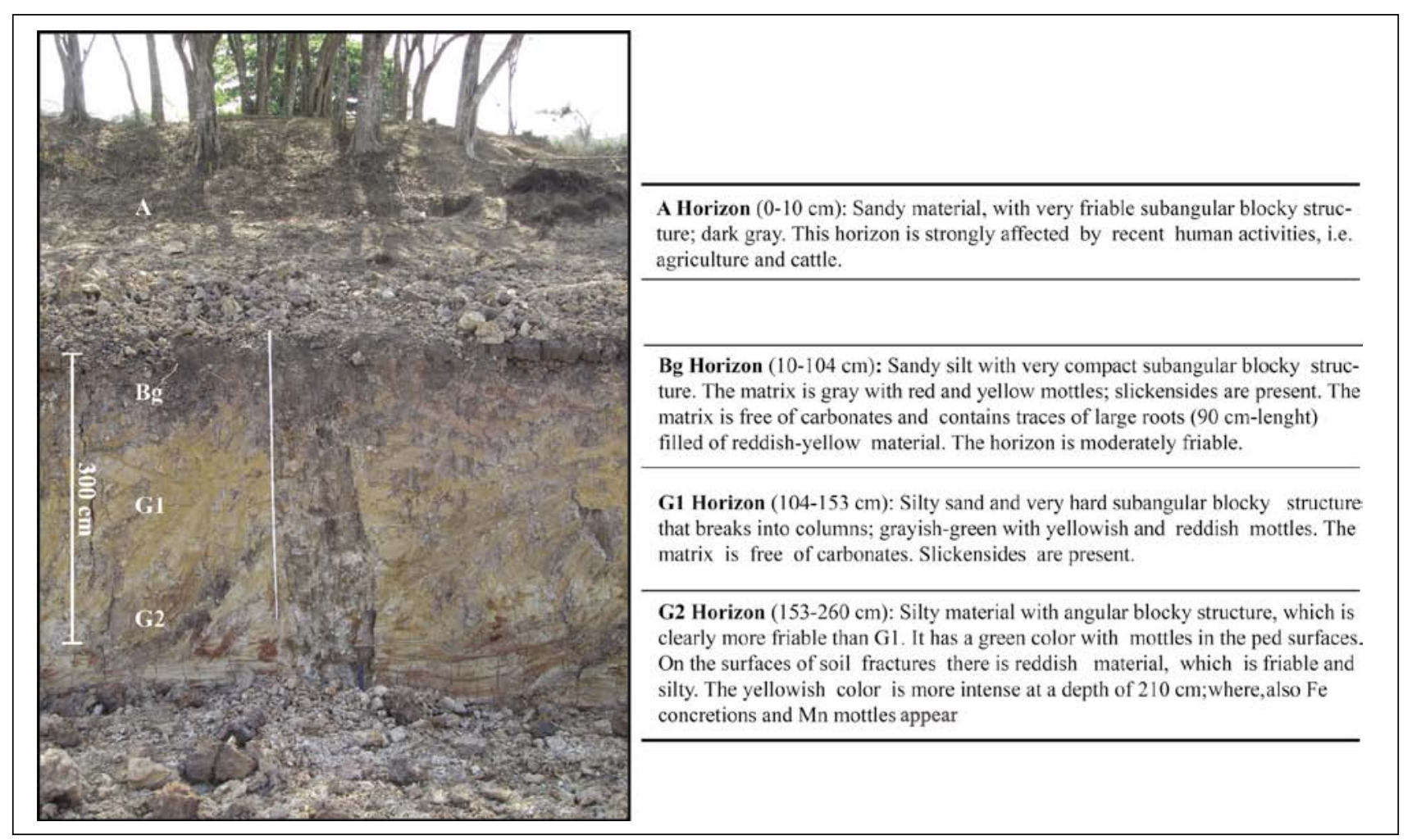

Fig. 4: Balancán: composite profile and field description.

Abb. 4: Gesamtprofil und Geländeaufnahme für Balancán.

doses were also derived from the K-feldspar fraction. A post-IR IRSL protocol was applied using a preheat and cutheat temperature of $320^{\circ} \mathrm{C}$, IR stimulation at $50^{\circ} \mathrm{C}(200$ s) and post-IR IR stimulation at $290^{\circ} \mathrm{C}(200 \mathrm{~s}$; referred to as pIRIR ${ }_{290}$ ) (Thiel et al. 2011; Buylaert et al. 2012). An IR clean-out at $325^{\circ} \mathrm{C}(100 \mathrm{~s})$ complemented the measurement cycle. The initial $2 \mathrm{~s}$ minus a background of the last $40 \mathrm{~s}$ were used for equivalent dose calculation.

Dosimetry samples were dried and homogenized prior to packing $\sim 50 \mathrm{~g}$ into N-type beakers. High-resolution gamma-counting was conducted at the Leibniz Institute for Applied Geophysics (Hannover, Germany). Conversion to dose rates is based on the values given in GuÉrin et al. (2011). The cosmic ray contribution was calculated using the data given in Prescott \& HutTON (1994), and for all samples a water content of $25 \pm$ $5 \%$ was used. Equivalent doses, dose rates and ages are listed in Table 1.

\section{Results}

\subsection{Heavy minerals}

An overview of the heavy minerals found is shown in Figures 6 and 7. The heavy mineral composition of the paleosols and river sediments of the Usumacinta shows a clear pattern for all studied samples (Figure 5): There is a dominance of opaque minerals. These show signs of weathering (Table 2 ), indicated by leucoxene whitish rings. These observations are specifically pronounced in the alluvial sediments with concentrations ranging from $14.5 \%$ to $59.6 \%$. The samples from the TB II section (the youngest paleosols with strong evidence of human occupation; see Table 2) have the lowest concentration of fresh opaque minerals for all studied sam- ples (including Balancán). The smallest amount is found in horizons $3 \mathrm{~A}$ and $3 \mathrm{C}$, where it is about $4.5 \%$. The underlying horizons show values between $22 \%$ and $33 \%$. Epidote is the second most abundant mineral ( $1 \%$ to $21 \%$ ), with a notable increase in the lowest horizons (5Bss, 5BC, 5C). Interestingly, there are high concentrations of pyroxene in the three uppermost horizons (AC-2A-2AC) with values between $12 \%$ and $22 \%$; these are the highest concentration of all studied profiles (Table 2). Furthermore, these horizons show the highest concentrations of green (11\%) and brown amphibole (5\% to $9 \%$ ). In general green amphibole has greater abundance than brown hornblende. The presence of calcite is more or less constant throughout the profile, with the exception of the uppermost horizons (AC-2A-2AC-3A), where the content ranges from $18 \%$ to $55 \%$. Chlorite and zoisite were also found; they do not exceed $4.5 \%$, again with the highest concentrations in the uppermost horizons. The lower part of the profile (4Bk-5As-5Bss-5BC-5C) shows remarkable heavy mineral patterns with relatively high concentrations of rutile (1.3\% to $2.5 \%$ ), chromospinel $(3.0 \%$ to $5.8 \%)$, turmaline ( $1.1 \%$ to $4.0 \%)$, kyanite (1.4\% to $2.0 \%)$ and monazite $(2.0 \%$ to $2.8 \%)$. It is interesting to note that the $4 \mathrm{Bk}$ horizon is the only layer with well-rounded minerals, including coarse silt size, and the presence of volcanic glass on the surface of amphiboles.

For the alluvial units, the most striking aspect is the high concentration of volcanic material represented by amphibole, which is coated by volcanic glass and pyroxenes with dissolution surfaces. However, is not possible to identify a general pattern throughout the sequence except for the presence of calcite in percentages between $1 \%$ and $59 \%$ (the major part located in the middle of the sedimentary sequence). The accumulation of minerals is less homogene- 


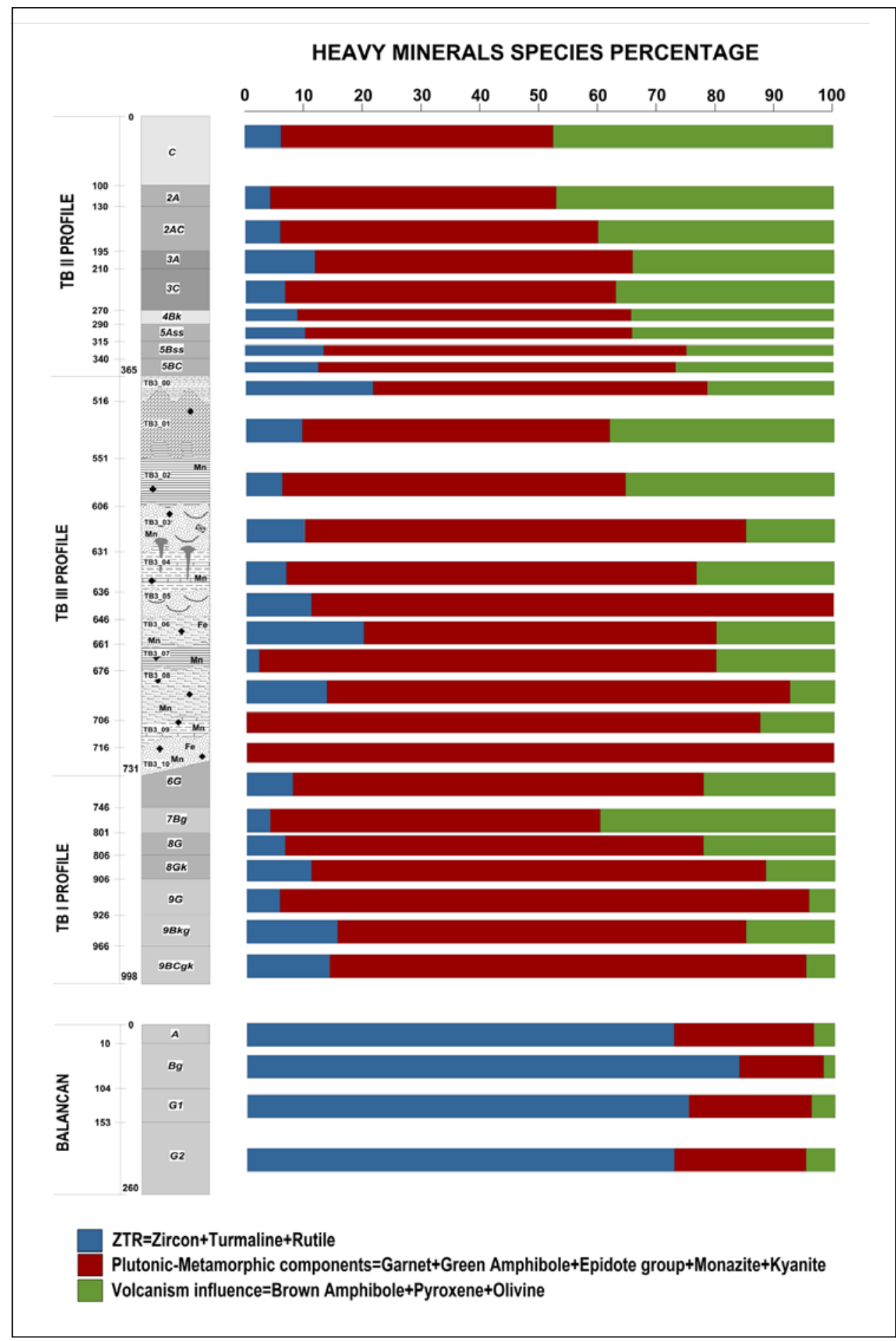

Fig. 5: Tierra Blanca and Balancán profiles and relative abundance of heavy minerals.

Abb. 5: Zusammenstellung der Profile und relative Vorkommen der Schwerminerale für Tierra Blanca und Balancán.

ous compared to the soil profiles. There seems to be a weak tendency of enhanced concentrations for green amphibole, epidote, and pyroxene in the bottom of the profile. Garnet is only of importance in the middle part of the profile $(3.4 \%$ to $6.0 \%$ ).

The lower part of the TB profile (TB I; Figure 3) shows a more regular pattern in the mineral concentration. The most important characteristic is the highest presence of epidote ranging from $20.8 \%$ to $28.3 \%$, and the concentration of stable minerals (garnet, titanite, zircon, zoisite, rutile, chromospinel, monazite, and kyanite) with a decrease of less stable minerals (like amphibole). Many of these minerals have a metamorphic source (from moderate to high grade metamorphic phases). The influence of the volcanic source is less evident, however, pyroxene and olivine show large concentrations (mainly in the upper part of the profile, i.e. 6G-7Bg-8G-8Gk). Horizons $6 \mathrm{G}$ and $9 \mathrm{G}$ show the largest abundance of opaque minerals (Table 2). There is clearly a change in the mineral composition at the boundary between $6 \mathrm{G}$ and the lowermost part of the silty sediment (Figure 3), where the metamorphic components dominate. The amount of calcite is much smaller than for TB II and TB III ( $0.2 \%$ to $3.5 \%)$.

The Balancán profile shows clear differences in comparison to the Tierra Blanca sections; there ultrastable minerals are present (Figure 5). The sequence shows very high contents of zircon (17\% to $25.5 \%$ ), rutile (3.4\% to $8.4 \%$ ), and titanite $(2.0 \%$ to $5.3 \%)$. There is only very little epidote and hardly any calcite present (Table 2). 


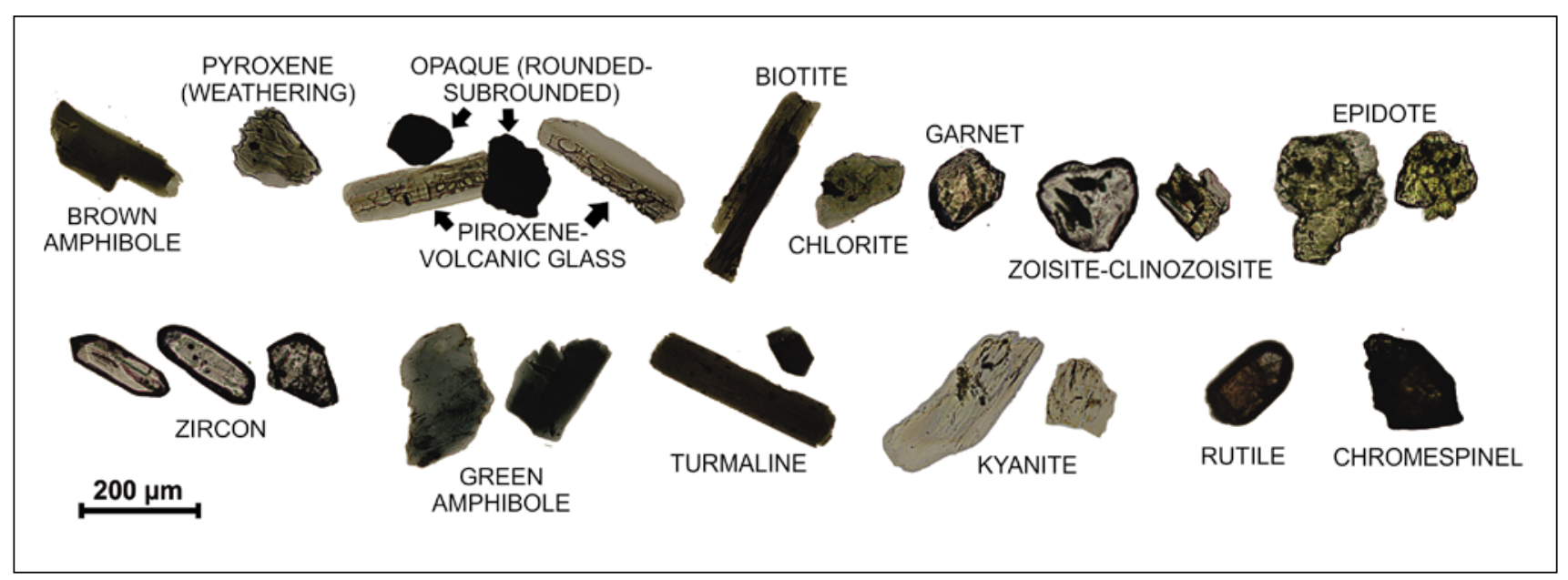

Fig. 6: Heavy minerals under the petrographic microscope using plane polarized light.

Abb. 6: Ausgewählte Schwerminerale unter dem petrograpischen Mikroskop unter der Verwendung von eben-polarisiertem Licht.

\subsection{Micromorphology of selected horizons}

Horizon 3A (TB I) is dominated by a clayey-silty texture; there are only a few sand grains. The structure evidences vertic features (angular blocky structure with porostriated b-fabric; Figure 7a). Weathered volcanic glass is also present (Figure 7b). 9Bkg horizon is very clayey but contains some sand grains, which are mainly composed of quartz (Figures $7 \mathrm{c}$ and $7 \mathrm{~d}$ ). A few micas are also present; these are all highly weathered. Clay coatings are frequent. In TB III the most remarkable feature in the silty sediment is the strong lamination that is clearly shown not only in the profile (Figure 2c) but also in the scanned section (Figure 7e). This laminated sediment is dominated by volcanic glass which is angular (Figure $7 \mathrm{f}$ ).

\section{Discussion}

\subsection{Ages of the paleosol units and pedostratigraphy}

The gleyic paleosols (horizons 6 to 9) found in TB I are clearly much older than the overlying succession (TB III and TB II). Horizon 9BCgk was luminescence dated to $>65 \mathrm{ka}$ (quartz OSL; sample 2464); the feldspar $\left(\mathrm{pIRIR}_{290}\right)$ yielded an age of $123 \pm 6 \mathrm{ka}$ (Table 1$)$. This age represents the age of the parent material of paleosol 9, i.e. the paleosols are younger. One might argue that alluvial sediments are not well-bleached prior to deposition, i.e. the luminescence signal is not reset, which would result in an age overestimate. It is very unlikely that the alluvial sediments at this site carry a large residual dose, which is shown by the youngest sample (horizon $3 \mathrm{C}$; sample 2462): Its luminescence age is in very good agreement with the radiocarbon ages of the over- and underlying layers (Table 1). The radiocarbon age of 5450-5380 cal. B.P. for the lowermost paleosol (horizon 9Bkg; Table 1) was derived from neoformed carbonates; they postdate the age of the sediments. The gleyic paleosols show strong redoximorphic features, leaching (carbonates are absent in the groundmass) and intense clay accumulation (including well preserved clay coatings). All these characteristics point to pedogenesis in a moist environment, sometimes accompanied by water-logging that is hardly compatible with the formation of calcite. Thus, carbonates precipitated much later, after environmental conditions changed. As a consequence, the age of the carbonate concretions (5450-5380 cal. B.P.) cannot be interpreted as the age of the first intensive pedogenetic phase. According to the luminescence ages of the parent material and of the overlying alluvial sequence (sample 2463; cf. Table 1) the soils formed after $123 \pm 6$ ka but prior to $9 \pm 2$ ka.

The latter age is the only age estimate for the silt sediment between the two pedocomplexes (TB I and TB II) (cf. Figure 3). The deposition thus took place during the Holocene. The underlying pedocomplex had a very long time for its development (i.e. from $123 \pm 6$ ka until the Holocene). The presence of several phases of sedimentation and soil formation (to constitute each paleosol in the pedocomplex) take a considerable time span, especially if one takes into account the weathering degree of each paleosol, which is higher than for the soils of the overlying sequence.

However, one has to consider that the migration of the river system might have caused erosion of parts of the Late Pleistocene sequence. Evidence of such erosional phases are as follows: None of the Gleysols have A horizons, and there are changes in the heavy mineral distribution, which clearly reflects discontinuities (Figure 5). Such discontinuities are obvious between $8 \mathrm{G} / 7 \mathrm{Bg} ; 7 \mathrm{Bg} / 6 \mathrm{G}$, and $6 \mathrm{G} /$ silty sediment (the latest is the most contrasting).

Solís-Castillo et al. (2013) have presented a chronological framework based on radiocarbon and archeological evidence for the younger paleosols (TB II). They presented an age of 2340-2300 cal B.P. for soil horizon 5Ass (Figure 3), and they found ceramic belonging to the Formative culture, which agrees with the dating result. The presence of Vertisols, which formed during the same period, has been documented in other areas of the Mayan Lowlands (DAHLIN et al. 1980; Pope \& Dahlin 1989, 1993; Dunning \& BeAcH 2004; BEACH et al. 2006; DunNING et al. 2006).

Horizon 3A was radiocarbon dated to $1140-970$ cal. B.P (Solís-CAstillo et al. 2013). The luminescence age of $2.1 \pm$ 0.5 ka for horizon 3C fits well into this chronological framework, and can give some insights about the period of relative landscape stability. The age from the $3 \mathrm{C}$ horizon represents the time when the sediment was deposited, that is the maxi- 
Tab. 2: Summary of the heavy mineral analysis results (in percentage).

Tab. 2: Zusammenfassung der Ergebnisse der Schwermineralanalyse (angegeben in Prozent).

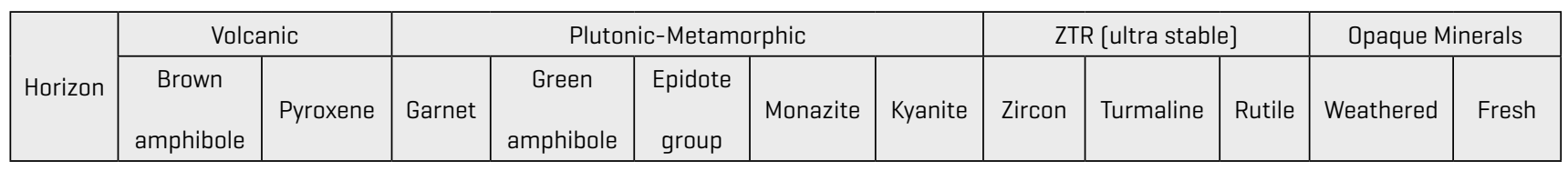

Tierra Blanca II

\begin{tabular}{|c|c|c|c|c|c|c|c|c|c|c|c|c|}
\hline C & 8.95 & 17.02 & 2.28 & 11.05 & 8.07 & 0.00 & 0.00 & 2.28 & 0.00 & 1.05 & 25.26 & 0.00 \\
\hline $2 A$ & 5.32 & २2.20 & 1.28 & 11.19 & 13.03 & 0.00 & 0.00 & 0.73 & 0.73 & 1.10 & 22.02 & 0.00 \\
\hline $2 A C$ & 6.52 & 11.86 & 7.31 & 2.17 & 12.85 & 0.00 & 0.59 & 1.38 & 0.20 & 1.19 & 26.68 & 0.99 \\
\hline $3 A$ & 0.00 & 0.00 & 0.25 & 0.75 & 1.01 & 0.00 & 0.00 & 0.25 & 0.00 & 0.00 & 4.52 & 5.03 \\
\hline $3 C$ & 1.67 & 0.83 & 0.83 & 3.33 & 2.92 & 0.00 & 0.00 & 2.08 & 0.42 & 0.00 & 4.58 & 0.83 \\
\hline 4Ck & 1.42 & 3.30 & 6.60 & 5.19 & 10.85 & 0.00 & 0.47 & 2.36 & 0.94 & 0.00 & 33.02 & 3.30 \\
\hline 5Ass & 7.17 & 7.89 & 2.15 & 2.15 & 10.04 & 2.51 & 1.43 & 6.45 & 3.94 & 0.72 & 27.60 & 6.09 \\
\hline 5Bss & 6.31 & 4.32 & 1.99 & 1.33 & 20.60 & 1.99 & 1.99 & 3.99 & 1.66 & 1.33 & 24.25 & 6.31 \\
\hline $5 \mathrm{BC}$ & 6.20 & 5.43 & 4.65 & 1.94 & 17.83 & 1.94 & 0.00 & 3.49 & 1.16 & 1.16 & 29.07 & 4.26 \\
\hline $5 C$ & 4.13 & 6.06 & 3.31 & २.२० & 20.94 & 2.75 & 0.83 & 6.61 & 3.31 & 2.48 & 27.00 & 2.75 \\
\hline
\end{tabular}

Tierra Blanca III

\begin{tabular}{|c|c|c|c|c|c|c|c|c|c|c|c|c|}
\hline TB3_0 & 11.01 & 12.50 & 0.89 & 7.74 & 20.83 & 1.79 & 1.19 & 2.68 & 2.38 & 1.19 & 24.40 & 1.49 \\
\hline TB3_1 & 1.74 & 6.67 & 2.32 & 2.32 & 7.83 & 0.58 & 0.00 & 1.16 & 0.00 & 0.29 & 19.13 & 7.83 \\
\hline TB3_2 & 2.54 & 0.00 & 1.69 & 4.24 & 5.93 & 0.00 & 0.00 & 1.69 & 0.00 & 0.00 & 50.00 & 16.10 \\
\hline TB3_3 & 0.78 & 7.03 & 1.56 & 4.69 & 14.06 & 0.78 & 0.00 & 2.34 & 0.00 & 0.00 & 30.47 & 17.19 \\
\hline TB3_4 & 0.00 & 0.00 & 0.81 & 2.42 & 3.23 & 0.00 & 0.00 & 0.81 & 0.00 & 0.00 & 14.52 & 16.13 \\
\hline TB3_5 & 6.78 & 3.39 & 3.39 & 13.56 & 11.86 & 0.00 & 0.00 & 8.47 & 1.69 & 0.00 & 18.64 & 3.39 \\
\hline TB3_6 & 7.69 & 3.85 & 8.97 & 19.23 & 15.38 & 0.00 & 0.00 & 1.28 & 0.00 & 0.00 & 23.08 & 2.56 \\
\hline TB3_7 & 1.82 & 1.82 & 5.45 & 12.73 & 18.18 & 0.00 & 0.00 & 3.64 & 3.64 & 0.00 & 14.55 & 1.82 \\
\hline TB3_8 & 1.75 & 1.75 & 0.00 & 3.51 & 21.05 & 0.00 & 0.00 & 0.00 & 0.00 & 0.00 & 59.65 & 7.02 \\
\hline TB3_9 & 0.00 & 0.00 & 3.09 & 0.00 & 6.79 & 0.00 & 0.00 & 0.00 & 0.00 & 0.00 & 61.11 & 27.16 \\
\hline TB3_10 & 3.55 & 8.28 & 2.37 & 18.93 & 14.20 & 1.79 & 0.00 & 1.78 & 2.37 & 0.00 & 37.87 & 4.14 \\
\hline
\end{tabular}

Tierra Blanca I

\begin{tabular}{|c|c|c|c|c|c|c|c|c|c|c|c|c|}
\hline $6 G$ & 2.49 & 7.21 & 2.62 & 0.98 & 22.62 & 0.00 & 0.00 & 2.30 & 1.49 & 0.50 & 25.87 & 0.50 \\
\hline $7 \mathrm{Bg}$ & 0.66 & 2.53 & 2.11 & 0.84 & 28.27 & 0.00 & 0.33 & 2.11 & 0.33 & 0.33 & 37.70 & 4.92 \\
\hline $8 G$ & 0.84 & 2.70 & 1.96 & 0.25 & 26.72 & 0.98 & 0.00 & 2.45 & 0.00 & 0.42 & 38.40 & 9.28 \\
\hline $8 G k$ & 1.96 & 1.22 & 6.40 & 1.22 & 28.96 & 1.69 & 0.00 & 0.91 & 0.25 & 1.96 & 44.61 & 0.98 \\
\hline $9 \mathrm{G}$ & 0.00 & 5.38 & 6.01 & 0.95 & 20.89 & 1.72 & 0.00 & 5.70 & 0.30 & 1.22 & 36.89 & 10.37 \\
\hline $9 \mathrm{Bkg}$ & 1.90 & 0.70 & 6.32 & 1.75 & 23.51 & 0.61 & 2.85 & 5.26 & 0.32 & 1.58 & 25.63 & 13.29 \\
\hline 9BCgk & 1.05 & 7.21 & 2.62 & 0.98 & २2.62 & 0.95 & 0.35 & 2.30 & 0.00 & 1.05 & 32.28 & 4.56 \\
\hline
\end{tabular}

Balancan

\begin{tabular}{|c|c|c|c|c|c|c|c|c|c|c|c|c|}
\hline$A$ & 1.55 & 0.00 & 0.00 & 7.75 & 1.55 & 0.78 & 0.00 & 24.42 & 0.39 & 7.36 & 44.96 & 3.88 \\
\hline $\mathrm{Bg}$ & 0.62 & 0.00 & 0.00 & 0.62 & 2.80 & 0.93 & 0.62 & 20.81 & 0.00 & 8.39 & 25.16 & 30.12 \\
\hline $\mathrm{G}_{1}$ & 0.76 & 0.38 & 0.00 & 1.14 & २.28 & 1.14 & 1.14 & 19.77 & 0.00 & 3.42 & 46.77 & 10.27 \\
\hline $\mathrm{G}_{2}$ & 1.06 & 0.53 & 0.00 & 3.19 & 2.66 & 1.06 & 0.53 & 17.02 & 1.60 & 6.38 & 48.40 & 6.38 \\
\hline
\end{tabular}

mum age of the soil. In contrast, the date obtained from the bulk organic matter of $3 \mathrm{~A}$ represents the minimum age of the paleosol, just prior to its burial. These ages show that the soil formed within 1000 years (the difference between the age of $3 \mathrm{C}$ and $3 \mathrm{~A}$ horizons: beginning and end of pedogenesis).

\subsection{Provenance and landscape evolution: Mineralogical evidences}

Mineralogical assemblages are similar among all studied profiles (Figure 5). However, in the upper units, higher amounts of volcanic minerals can be detected. It is clear 

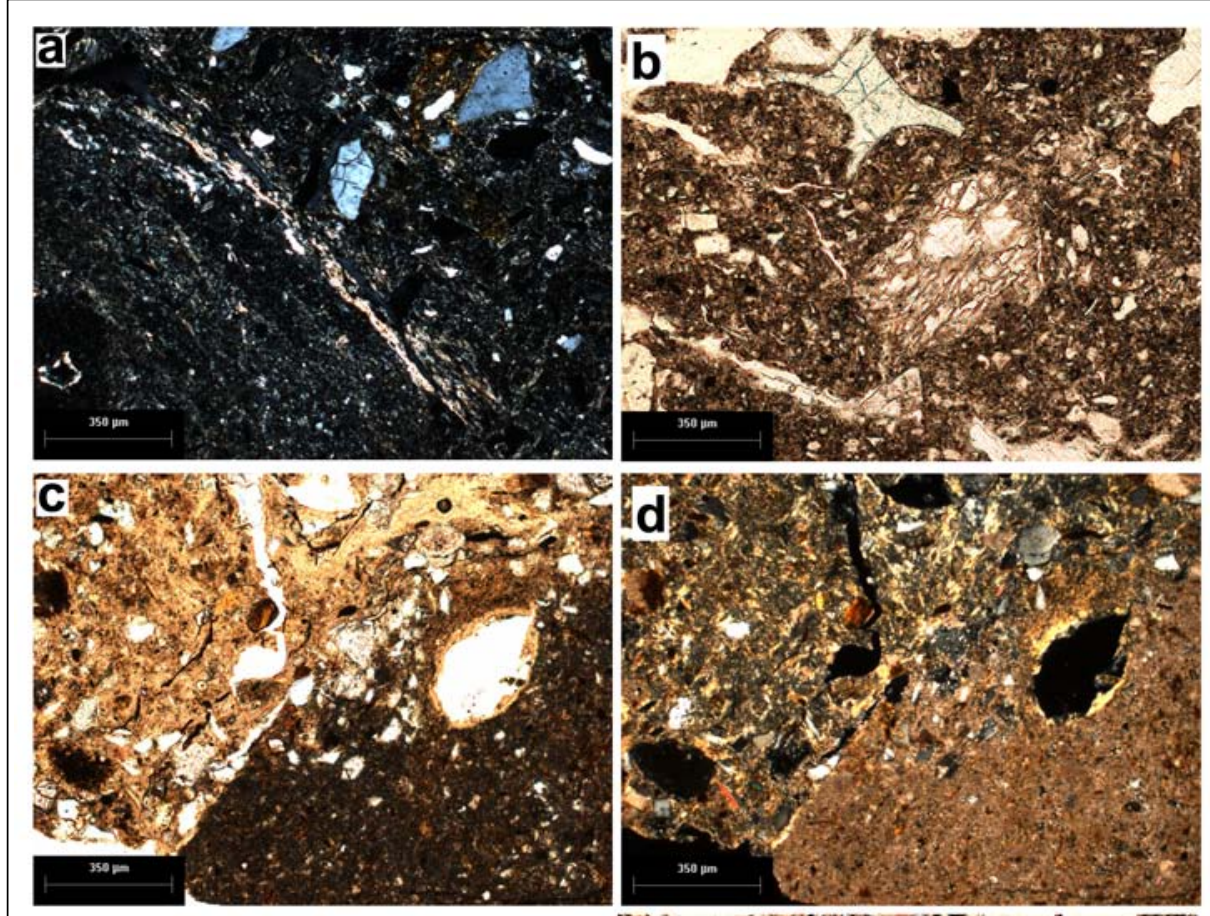

Fig. 7. Micromorphology of selected horizons: (a) porostriated $b$-fabric in horizon $3 A T B$ I, cross polarized light (XPL); (b) weathered pumice in horizon $3 A T B I$,
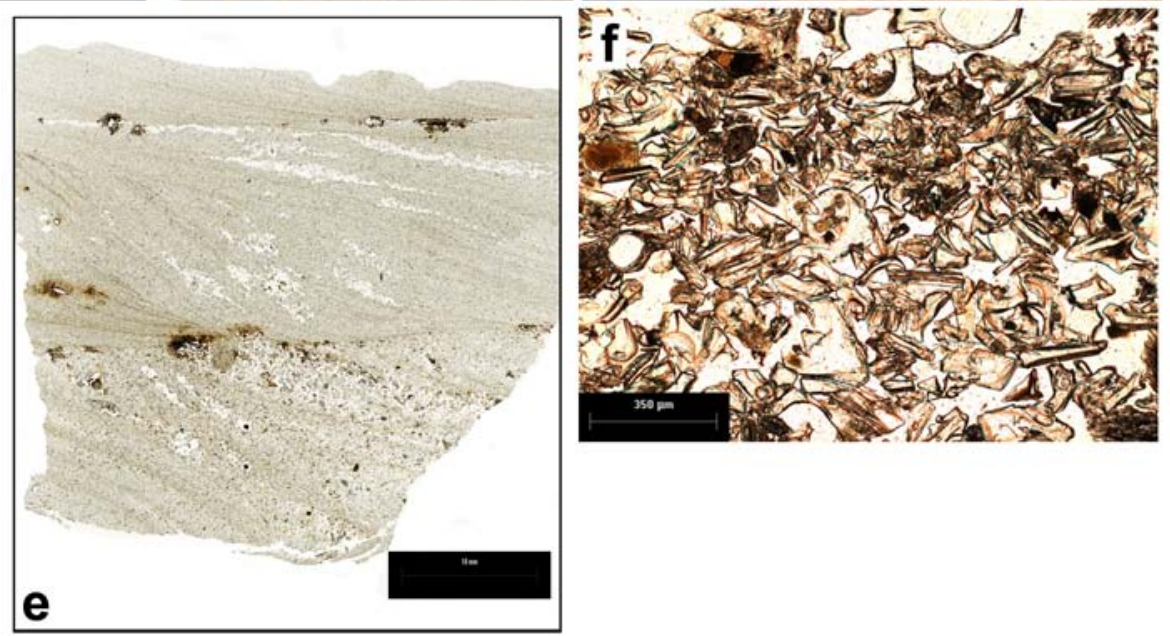
plane-polarized light (PPL); (c) Clay coatings and pedogenetic carbonates in $8 \mathrm{Bkg}$ horizons (PPL); (d) Clay coatings and pedogenetic carbonates in $8 B \mathrm{~kg}$ horizons (XPL); (e) silty sediment from TB III; $(f)$ volcanic glass in the silty sediment of $T B$ III (PPL).

Abb. 7: Mikromorphologie von ausgewählten Horizonten: (a) poro-streifiges b-Fabric aus Horizont $3 A$ TBI, gekreuztploarisiertes Licht (XPL); (b) verwitterter Bims aus Horizont $3 A$ TB1, ebenpolarisiertes Licht (PPL); (c)Toncutane und pedogenes Karbonat aus Horizont $8 B k g$ (PPL); (d) Toncutane und pedogenes Karbonat aus Horizont 8Bkg (XPL); (e) silitiges Sediment aus TB III; $(f)$ vulkanisches Glas im siltigen Sediment aus TB III (PPL).

that the active volcanism in the Central America Volcanic Arc can provide such minerals to the alluvial plain of Tabasco (Figure 1). It is interesting to note that these minerals have angular and subangular shapes suggesting transport by slow river flow. It is likely that they originate from ash falls coming directly from the primary source.

One of the most intriguing materials is the silty sediment in the upper part of TB III (TB3_00). Its sand fraction contains a mixture of volcanic, metamorphic, and plutonic minerals, but in the thin sections, we clearly observe the dominance of laminated volcanic materials, particularly, volcanic glass (Figure 7). Based on the mineralogical data and an age of 9 $\pm 2 \mathrm{ka}$ of the sediment, in which the minerals were found, we attempt to correlate the mineral assemblage to a possible eruption in the surrounding area. According to ARCE (personal communication), it is likely that the Tacana volcano (Figure 1) provided the volcanic material found in the sediment. This volcano had large voluminous eruptions during the Late Pleistocene (ARCE et al. 2012). This material can subsequently be reworked over short distances by the river. However, a detailed analysis is needed to draw any final conclusions on the provenance of this sample.

The heavy mineral associations (Figure 8 ) of the investigated sediments imply a broad range of metamorphic source rocks, suggesting the influence of different tectonic environments. Zircon-Turmaline-Rutile (ZTR) suit minerals (HUBERT 1962) are common in acidic to intermediate granitoid rocks as well as in mature siliciclastic sediments and some metamorphic rocks (e.g. von EyNATTEN \& GAUPP 1999). The highest concentrations of ZTR in the Balancán profile can be interpreted as originating from an ancient sedimentary recycling phase, where the dissolution and pedogenesis reduces the less stable minerals (GARZANTI \& ANDo 2007). It is interesting to draw attention to the origin of the rutile phases: The majority of detrital rutile comes from medium to high grade metamorphic rocks (ForCE 1980; 1991) and recycled sediments. The same mineralogical evidence is found in the metamorphic complex of Southeast Guatemala (garnet, kyanite, rutile schists, and abundant ortho-gneisses, which range from mafic to granitic); this is where the Usumacinta River starts. In consequence, our data suggest that the river transported material from this region. 
Additionally, the dominance of euhedral tourmaline indicates proximity to the source rocks and short transport from a predominantly low-grade metamorphic source (SINGH et al. 2004). Chlorite and epidote were also derived from lowgrade metamorphic series, whereas gneisses, granitoid rocks and recycled sedimentary rocks are possible sources of (ultra) stable minerals like zircon, tourmaline and rutile. Kyanite indicates the presence of high-pressure metamorphic rocks in the catchment; it has to be noted that it is not a dominant mineral in the assemblage. SolARI et al. (2011) have documented areas in Central Guatemala with high-pressure metamorphic rocks. As this area is cut northwards by the Chixoy River until it joins with the Passion River (a tributary of the Usumacinta; Figure 1), it is very likely that this is the sediment source for the alluvial plain.

The presence of chromspinel and epidote group minerals are indicative for a source area with ophiolite complexes associated with suture zones. The most important suture zone near the study area is in Guatemala where the Usumacinta River springs (Figure1). At present, this suture zone is part of a major left lateral strike slip boundary between the North American plate to the north (locally known as the Maya block) and the Caribbean plate (locally the Chortís block) to the south (BRUECKNER et al. 2009).

The units in the Mayan block include the Chuacús metamorphic complex, recently shown to include eclogitic lenses that record a Late Cretaceous event (OrTEGA-GutiERrez et al. 2007; MARTEns et al. 2007, 2010), Paleozoic sedimentary rocks of the Santa Rosa Group, low-grade meta-sediments (white mica-chlorite schists, quartzite, and minor marble) associated with antigorite schist/mélange and deformed granites. The Chortís block contains the green schist facies, San Diego phyllite, the amphibolites facies Las Ovejas complex, and relatively undeformed granitoids. Numerous U-Pb zircon ages from granites and their host gneisses north of the fault resulted in Late Proterozoic (Grenville), Carboniferous, and Triassic ages as well as a metamorphic event at c. $70 \mathrm{Ma}$ (MARTENs et al. 2007, 2010).

\subsection{Implication for human land use}

Our data can provide some insight into the land use of the region, especially with respect to fluctuations of human occupation and to the ceramic production. It is obvious that the presence of well-drained soils in Tierra Blanca (TB II) favored human occupation. These paleosurfaces were not inundated and represented stable areas for human activities, which were more or less continuous throughout the last 2-3 millennia. In contrast, other archeological sites such as Palenque, even though bigger in size, had less continuous occupation (for details see LIENDo et al. 2013).

Further, is interesting to note that the suite of heavy minerals in paleosols and sediments found in Tierra Blanca has also been documented in petrographic studies about the pottery of the region (OBANDo et al. 2011). It can therefore be deduced that the material at Tierra Blanca is very suitable for the manufacturing of the pottery. The gleyic paleosols at the base provided clay for the clay matrix of the ceramic, while the volcanic glass found in the silty sediment (TB III) could be used as temper. Thus, this area has been of great importance to the humans at this time.

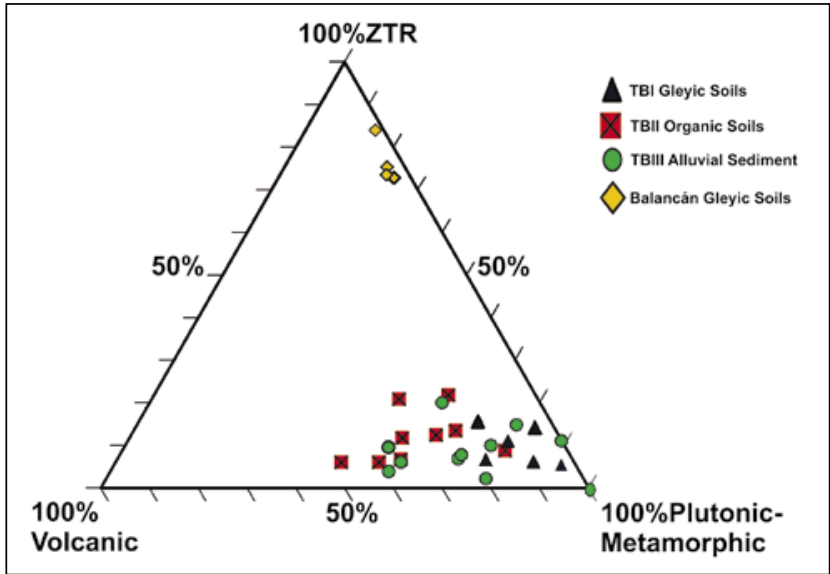

Fig. 8: Ternary diagram with the relative mineralogical suites of heavy minerals. $Z T R=$ zircon + turmaline + rutile $;$ Plutonic-Metamorphic $=$ garnet + green amphibole + epidote group + monazite + kyanite $;$ Volcanic $=$ brown amphibole + pyroxene + olivine.

Abb. 8: Phasendiagramm für die mineralogischen Charakter der Schwerminerale. $Z T R=$ Zirkon + Turmalin + Rutil; plutonisch-metamorph $=$ Granat + grüner Amphibol + Epidotgruppe + Monazit + Kyanit $;$ Vulkanisch = brauner Amphibol + Pyroxen + Olivin.

\section{Conclusions}

The alluvial terrace system of the Usumacinta River reflects the Late Quaternary pedostratigraphy of the region. On the alluvial Pleistocene terrace, soils with gleyic features are present. On the oldest Holocene terrace (HT2), we found the remnants of the gleyic paleosols in sediment dated to $123 \pm 6 \mathrm{ka}\left(\mathrm{pIRIR}_{290}\right)$, while on the younger terraces (HT1, HT0) only less developed paleosols are present.

Metamorphic and plutonic terrains of the south of Mexico and Guatemala were identified as the main source of sediments for the Tierra Blanca area. However, the heavy mineral assemblages reflect some changes in provenance throughout time. Soils located on the older terraces, as in Balancán, show the presence of ultra-stable minerals; these reflect prolonged landscape stability and soil formation. In consequence, this mineralogical set can be used for pedostratigraphic correlation and tracing the oldest terraces in the area.

Larger amounts of volcanic minerals in the younger paleosols may allow for pointing out areas which were affected by eruptions. Further, the mineral compositions, if compared with those of ceramics might make it possible to trace the source regions for ceramic production.

\section{Acknowledgement}

This research has been funded by PAPIIT, (grants no. IN117709 and IN110710; E. Solleiro-Rebolledo), a bilateral project (no. CONACYT-DLR J010/0705/09 and CONACYT 166878; E. Solleiro-Rebolledo), and Coordinación de Estudios de Posgrado (UNAM). Funding from the Bundesministerium für Bildung und Forschung, Internationales Büro (German Ministery for Education and Research, International office) in form of the bilateral project MEX 08/002 is very much appreciated. We thank Christina Wiesbeck, Daniel Jäger, Jaime Díaz and Serafín Sánchez for assistance during field work. 


\section{References}

Arce, J.L., Macías, J.L., Gardner, J.E., RAngel, E. (2012): Reconstruction of the Sibinal Pumice, an andesitic Plinian eruption at Tacaná Volcanic Complex, Mexico-Guatemala. - Journal of Volcanology and Geothermal Research 217-218: 39-55.

Banerjee, D., Murray, A.S., Bøtter-Jensen, L., Lang, A. (2001): Equivalent dose estimation using a single aliquot of polymineral fine grains. - Radiation Measurements, 33: 73-94.

Beach, T., Luzzadder-Beach, S., Dunning, N. \& Scarborough, V. (2003): Depression soils in the lowland tropics of northwestern Belize. - In: Gomez-Pompa, A., Allen, M., Fedick, S.L., Jimenez-Osornio, J.J. (eds.): Lowland Maya Area: Three Millennia at the Human-Wildland Interface: 139-173; Binghamton, NY (Haworth Press).

Beach, T., Dunning, N., Luzzadder-Beach, S., Cook, D.E. \& Lohse, J. (2006): Impacts of the ancient Maya on soils and soil erosion in the central Maya Lowlands. - Catena, 65: 166-178.

BRUECKNER, H.K. \& ForCE, E.R. (1980): The provenance of rutile. - Journa of Sedimentary Petrology, 50: 485-488.

Brueckner, H.K., Avé Lallemant, H.G., Sisson, V.B., Harlow, G.E., Hemming, S.R., Artens, U., Tsujimori, T. \& Sorensen, S.S. (2009): Metamorphic reworking of a high pressure-low temperature mélange along the Motagua fault, Guatemala: A record of Neocomian and Maastrichtian transpressional tectonics. - Earth and Planetary Sciences Letters, 284: 228-235.

Bullock, P., Fedoroff, N., Jongerius, A., Stoops, G., Tursina, T. ひ BABEL, U. (1985): Handbook for Soil Thin Section Description. - 152 p.; Waine Research Publications, Wolverhampton, Ukraine

Buylaert, J.-P., Jain, M., Murray, A.S., Thomsen, K.J., Thiel, C. \& SohbaTI, R. (2012): A robust feldspar luminescence dating method for Middle and Late Pleistocene sediments. - Boreas, 41: 435-451.

Cabadas-Baez, H., Solleiro-Rebolledo, E., Sedov, S., Pi, T. \& Gama-CasTRO J. (2010): Pedosediments of karstic sinkholes in the eolianites of NE Yucatán: a record of Late Quaternary soil development, geomorphic processes and landscape stability. - Geomorphology, 122: 323-337.

Consejo de Recursos Minerales (1999): Monografía Geológico Minera del Estado de Tabasco. - 152 p.; Conabio, Mexico.

Cunningham, A.C. \& Wallinga, J. (2010): Selection of integration time intervals for quartz OSL decay curves. - Quaternary Geochronology, 5: 657-666.

Dahlin, B.H., Chambers, M.E. \& Foss, J.E. (1980): Project Acalches: Reconstructing the Natural and Cultural History of a Seasonal Swamp at E Mirador Guatemala; Preliminary Results. - In: MAThenY R. (ed.): El Mirador, Peten, Guatemala: An Interim Report. Publication 45. New World Archaeological Foundation; Provo, Utah.

Donnelly, T.W., Horne, G.S., Finch, R.C. \& Lopez, R.E. (1990): Northern Central America: The Maya and Chortis blocks. - In: Dengo, G., CASE, J.E. (eds.): The Geology of North America, Vol. H: The Caribbean Region: 37-76; Geological Society of America.

Duller, G.A.T. (2003): Distinguishing quartz and feldspar in single grain luminescence measurements. - Radiation Measurements, 37: 161-165.

Dunning, N.P. \& BEACH, T. (2004): Fruit of the Lu'um: Lowland Maya Soil Knowledge and Agricultural Practices. - Mono y Conejo, 2: 1-25.

Dunning, N.P., Luzzadder-BeAch, S.L., Beach, T., Jones, J.G., Scarborough, V. \& CulBert, T.P. (2002): Arising from the Bajos: The Evolution of a Neotropical Landscape and the Rise of Maya Civilization. - Annals of the Association of American Geographers, 92: 267-283.

DunNing, N., BEACH, T. \& LuzzAdDER-BEACH, S. (2006): Environmental variability among bajos in the southern Maya Lowlands and its implications for ancient Maya civilization and archaeology. - In: LuCERo, L., FAsH, B. (eds.): Pre-Columbian Water Management: 111-133; University of Arizona Press.

Einsele, G. (1992): Sedimentary Basins. - 648 p; Springer (Berlin).

Fedick, S.L., Flores-Delgadillo, M.L., Sedov, S., Solleiro-Rebolledo, E. \& Palacios-Mayorga, S. (2008): Adaptation of Maya Homegardens by Container Gardening in Limestone Bedrock Cavities. - Journal of Ethnobiology, 28: 305-317.

Fernandez F., Johnson, K., Terry, R., Nelson, S. \& Webster, D. (2005) Soil resources of the Ancient Maya at Piedras Negras, Guatemala. Soil Science Society of America Journal, 69: 2020-2032.

ForCE, E.R. (1980): The provenance of rutile. - Journal of Sedimentary Petrology, 50: 485-488.

ForCE, E.R. (1991): Geology of titanium-mineral deposits. - Geological Society of America Special Paper, 259: 112.

Garzanti, E. \& ANDo, S. (2007): Heavy mineral concentration in modern sands: implications for provenance interpretation. - In: MANGE, M.A.
\& Wright, D.T. (eds.): Heavy Minerals in Use: Developments in Sedimentology, 58: 517-545.

Guérin, G., Mercier, N. \& Adamiec, G. (2011): Dose-rate conversion factors: update. - Ancient TL, 29: 5-8.

Hernandez Santana, J.R., Mendez Linares, A.P. \& Bollo Manent, M (2012): Análisis morfoestructural del relieve noroccidental del Estado de Chiapas, México. - Revista Geográfica Venezolana, 53: 57-75.

Hodell, D., Brenner, M. \& Curtis, J.H. (2005): Terminal Classic drought in the northern Maya Lowlands inferred from multiple sediment cores in Lake Chichancanab (Mexico). - Quaternary Science Reviews, 24: 1413-1427.

Hubert, J.F. (1962): A zircon-tourmaline-rutile maturity index and the interdependence of the composition of heavy mineral assemblages with the gross composition and texture of sandstones. - Journal of Sedimentary Petrology, 32: 440-450.

Hughes, P.H. (2010): Geomorphology and Quaternary stratigraphy. The roles of morpho-, litho-, and allostratigraphy. - Geomorphology, 123: 189-199.

KomAR, P.D. (2007): The entrainment, transport and sorting of heavy minerals by waves and currents. In: Mange, M.A. \& Wright, D.T. (eds). Heavy Minerals in use. - Developments in Sedimentology, 58: 3-48.

Kraus, M.J. (2002): Basin-scale changes in floodplain paleosols: implications for interpreting alluvial architecture. - Journal of Sedimentary Research, 72: 500-509.

Martens, U., Mattinson, C.G., Wooden, J. \& Liou, J.G. (2007): Protolith and metamorphic ages of gneiss hosting eclogite in the Chuacús complex, Central Guatemala. - American Geophysical Union (AGU), EOS Transactions, 88(23), Joint Assembly Supplement, Abstract: U53A-08.

Martens, U., Weber, B. \& VAlencia, V.A. (2010): U/Pb geochronology of Devonian and older Paleozoic beds in the southwestern Maya Block, Central America: its affinity with Peri-Gondwanan terranes. - Geological Society of America Bulletin, 122: 815-829.

Mikesell, L.R., Schaetzl, R. \& Velbel, M.A. (2004): Hornblende etching and quartz/feldspar ratios as weathering and soil development indicators in some Michigan soils. - Quaternary Research, 62: 162-171.

Murray, A.S. \& WintLe, A.G. (2000): Luminescence dating of quartz using an improved single-aliquot regenerative-dose protocol. - Radiation Measurements, 32: 57-73.

Ortega-Gutiérrez, F., Solari, L.A., Ortega-Obregón, C., Elías-HerreRA, M., Morán-ICAL, S., Chiquín, M., Keppie, J.D., Torres de León, R. \& SCHAAF, P. (2007): The Maya-Chortís boundary: a tectonostratigraphic approach. - International Geology Review, 449: 996-1024.

Ortiz Perez, M.A., Siebe, C. \& Cram, S. (2005): Diferenciación ecogeográfica de Tabasco. In: Bueno, J., Álvarez, F. \& Santiago, S. (eds.) Biodiversidad del Estado de Tabasco: 305-322; Instituto de Biología, UNAM- CONABIO (Mexico).

PAdilla, R. \& SANCHEz, R.J. (2007): Evolución geológica del sureste mexicano desde el Mesozoico al presente en el contexto regional del Golfo de México. - Boletín de la Sociedad Geológica Mexicana, LIX: 19-42.

Pirkle, F.L., Pirkle, W.A. \& Pirkle, E.C. (2007): Heavy Minerals Sands of the Atlantic and Gulf Coastal Plains, USA. - In: MANGE, M.A. \& Wright, D.T. (eds): Heavy Minerals in use. - Developments in Sedimentology, 58: 1145-1234.

Pope, K.D. \& Dahlin, B.H. (1989): Ancient Maya Wetland Agriculture New Insights from Ecological and Remote Sensing. - Journal of Field Archaeology, 16: 87-106.

Prescott, J.R. \& Hutton, J.T. (1994): Cosmic ray contributions to dose rates for luminescence and ESR dating: large depths and long-term variations. - Radiation Measurements, 23: 497-500.

Retallack, G.J. (1990): Soils of the past. An introduction to paleopedology. - 404 p.; Blackwell Science (U. K.).

Rosenmeier, M.F., Hodell, D.A., Brenner, M. \& Curtis, J.H. (2002): A 4000-Year Lacustrine Record of Environmental Change in the Southern Maya Lowlands, Petén, Guatemala. - Quaternary Research, 57: 183-190.

Sedov S., Solleiro-Rebolledo, E., Fedick, S.L., Gama-Castro, J., PalaCios-Mayorga, S. \& VAllejo Gomez, E. (2007): Soil genesis in relation to landscape evolution and ancient sustainable land use in the northeastern Yucatan Peninsula, Mexico. - Atti della Società Toscana de Scienze Naturali di Pisa, Serie A, 112: 115-126.

Schatzl, R. \& Anderson, S. (2005): Soils: Genesis and Geomorphology. -791 p; New York.

Singh, B.P., PAWAR, J.S. \& KARLuPIA, S.K. (2004): Dense mineral data from the northwest Himalayan foreland sedimentary rocks and recent river sediments: evaluation of the hinterland. - Journal of Asian Earth Sciences, 23: 25-35 
Solís-Castillo, B., Solleiro-Rebolledo, E., Sedov, S., Liendo, R., Ortiz PÉrez, M.A., López-Rivera, S. (2013): Paleoenvironment and human occupation in the Maya lowlands of the Usumacinta River, Mexico. Geoarchaeology, 28: 268-288.

Solleiro-Rebolledo, E., Sycheva, S., Sedov, S., McClung de Tapia, E. Rivera-Uria, Y., Salcido-Berkovich, C., Kuznetsova, A., (2011): Fluvial processes and paleopedogenesis in the Teotihuacan Valley, México: Responses to late Quaternary environmental changes. - Quaternary International, 233: 40-52.

Thiel, C., Buylaert, J.-P., Murray, A., Terhorst, B., Hofer, I., TsukamoTO, S. \& Frechen, M. (2011): Luminescence dating of the Stratzing loess profile (Austria) - Testing the potential of an elevated temperature post-IR IRSL protocol. - Quaternary International, 234: 23-31.
Von Eynatten, H. \& Gaupp, R. (1999): Provenance of Cretaceous synorogenic sandstones in the Eastern Alps: constraints from framework petrography, heavy mineral analysis and mineral chemistry. - Sedimentary Geology, 124: 81-111.

West R.C., Psuty, N.P. \& Thom, B.G. (1969): The Tabasco lowlands of Southern Mexico. - 88 p.; Louisiana State University Press.

WRB, World Reference BAse for soll Resources (2006): A framework for international classification, correlation and communication: World Soil Resources Reports 103, Food and Agricultural Organization of the United Nations, Rome. 